\title{
SUKCESIJA NA PRODIŠČIH REKE SAVE
}

\author{
Matjaž Geršič \\ Cesta na Lipce 4, SI-4248 Lesce, Slovenija \\ e-mail: matjaz.gersic@siol.net
}

Izvirni znanstveni članek

COBISS 1.01

\section{Izvleček}

V članku je predstavljena biogeografska analiza rastlinstva na prodiščih. Rezultati temeljijo predvsem na analizi rezultatov terenskega kartiranja, ki je bilo opravljeno na devetih izbranih prodiščih v povirnih krakih reke Save. Obravnavani so bili človekovi posegi v prodišča ter funkcijski pomen prodišč. Na podlagi rezultatov je bil izdelan grafični model sukcesije na izbranih prodiščih.

Ključne besede: fizična geografija, biogeografija, sukcesija, pionirske rastlinske vrste, prodišče, reka Sava

\section{SUCCESSION ON THE POINT BARS OF THE SAVA RIVER}

\begin{abstract}
This article presents a biogeographic analysis of vegetation on point bars. The results are based primarily on an analysis of off-road mapping, which was conducted in nine selected point bars of the upper stream of the Sava River. Human interference and functional significance of point bars have been researched, too. As a result of our research a graphic model of succession on the point bars has been created.
\end{abstract}

Key words: physical geography, biogeography, succession, pioneer vegetation species, point bars, the Sava river 


\section{UVOD}

V biogeografskih raziskavah stopamo po meji med geografijo in biologijo. Kljub relativni mladosti biogeografije kot znanosti je njena metodologija tudi $\mathrm{v}$ slovenskem prostoru predvsem po zaslugi profesorja F. Lovrenčaka dodelana do te mere, da nelegalno v prostor biologije ne posežemo, so nam pa pri našem raziskovanju v veliko pomoč njeni izsledki, predvsem izsledki botanike.

Geografsko preučevanje rastlinstva zajema predvsem opis sedanje vegetacije, njeno razlago, izločitev ter omejitev vegetacijskih formacij in različne prikaze (zemljevidi, tematske karte, vegetacijski prerezi) (Lovrenčak 2003, 14).

Spremembe v rastlinstvu na Zemlji označujejo trije procesi: regeneracija, fluktuacija in sukcesija (Tivy 1993). V prispevku je natančneje obravnavana sukcesija, ki med drugim poteka tudi na rečnih prodiščih. V terenskih raziskavah je bilo zajetih devet prodišč v zgornjem toku reke Save. Na podlagi rezultatov smo izdelali model sukcesije na teh prodiščih.

\section{SUKCESIJA}

S pojmom sukcesija označujemo evolucijski razvoj neke združbe od golih tal do končne ustaljene združbe, ki je v dinamičnem ravnotežju s svojim okoljem. Celoten proces sukcesije sestavlja več sukcesijskih nizov. Ti nizi se v danem biotopu medsebojno nadomeščajo. Končna razvojna stopnja, ki nastane kot produkt sukcesije, je ustaljena združba oz. klimaks (Lovrenčak 2003, 149). Z drugimi besedami lahko rečemo, da gre pri sukcesiji za sosledje rastlinskih in živalskih združb na določenem območju, ki tečejo po naravni poti (Geografski terminološki slovar 2005, 380; Šilc 2000). ॥V sukcesijskem razvoju se vsaka naslednja združba pojavlja na višji stopnji organizacije. Pri tem se povečuje vrstna raznolikost, vezi med posameznimi členi so trdnejše, njihovi biotski odnosi pa so bolj zapleteni. Istočasno se kaže usmerjenost k omejevanju ali k zoževanju krogotoka osnovnih hranil, kot so dušik, ogljik, fosfor in kalcij, kar se doseže s kopičenjem organske snovi in njene vključitve v lastnosti biotopa. V razvojnih stopnjah poraščanja biotopa imajo večjo verjetnost preživetja tiste vrste, ki se hitro razmnožujejo in rastejo. V njihovi sestavi bo bolj malo vrst, a z velikim številom poedincev v populaciji. V zaključnih stopnjah sukcesijske vrste bodo nasproti temu uspešnejše vrste $\mathrm{z}$ manjšimi rastnimi, vendar konkurenčno močnejšimi sposobnostmi. V sestavi bo veliko vrst, a v njihovih populacijah bo malo poedincev« (Lovrenčak 2003, 149150).

Beseda sukcesija izvira iz latinske besede succedere, kar pomeni 'slediti za'. Poznamo dve vrsti sukcesije, to sta primarna in sekundarna. Primarna sukcesija nastopa na območjih, kjer je površje nastalo na novo in je zgrajeno iz kamnin, lave, vulkanskega pepela, peska, gline in nekaterih drugih mineralov (Medmrežje 1). Taka okolja so dandanes relativno redka, vendar ponekod še nastajajo (Medmrežje 2).

Za okolje, kjer poteka primarna sukcesija, je značilna odsotnost posameznih rastlin, rastlinskih združb, živali, žuželk, semen. Tudi prst kot mešanica mineralnih in organskih delcev ter živih organizmov tu ni prisotna. Če so bile na tem območju prej že prisotne združbe, sta sedaj rastlinstvo in sloj prsti popolnoma odstranjena ali prekrita, tako da je 
pionirskim združbam na voljo le mineralni substrat. Primeri okolij, kjer nastopa primarna sukcesija, so območja vulkanskih izbruhov, široka kamnita in peščena območja (sipine ipd.), območja, s katerih se je umaknil ledenik (Medmrežje 1; Medmrežje 2). Med okolja, kjer poteka primarna sukcesija, uvrščamo tudi novonastale kopne površine, kot so otoki, prodišča, ipd. (Medmrežje 2). Primarna sukcesija lahko traja od 50 do 1500 let (Tivy 1993).

\section{Slika 1: Primarna sukcesija}

Figure 1: Primary succession

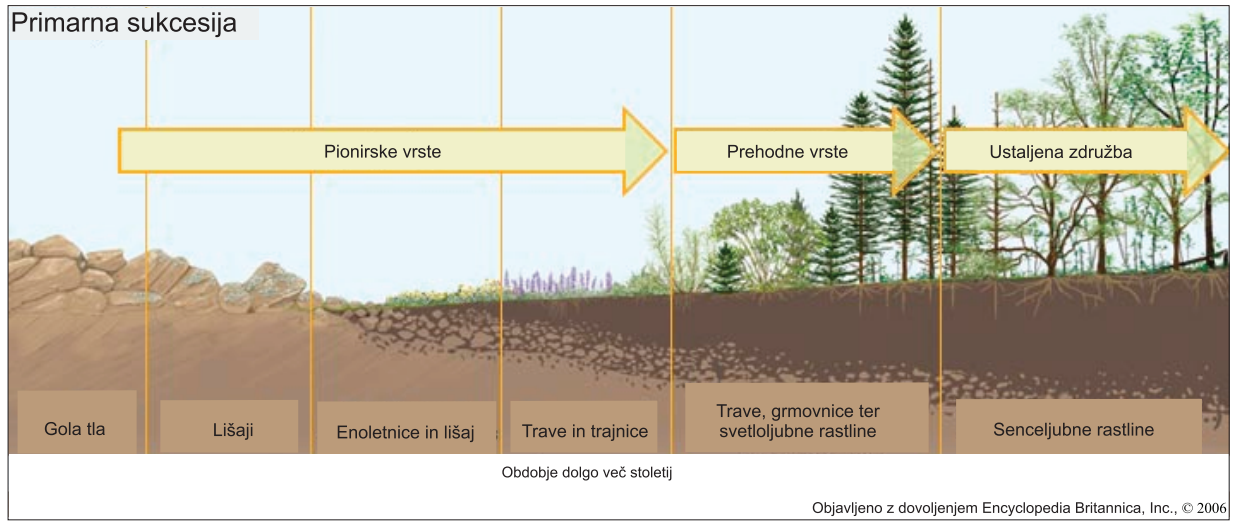

Vir/source: Encyclopedia Britannica 2009

Na območjih, kjer je bilo zaradi različnih vzrokov rastlinstvo popolnoma ali le deloma uničeno, sloj prsti pa je ostal, govorimo o sekundarni sukcesiji. Vzroki za uničenje rastlinstva so različni: požar, orkanski veter, suša, poplava, vnos invazivnih vrst, erozija ter različni človekovi posegi v naravnem okolju (kmetijska obdelava, razni tehnični posegi v prostor, degradacija rastlinstva; Tivy 1993, 157; Medmrežje 2). V kolikor so naravne nesreče ali drugi posegi tako intenzivni, da je odstranjena tudi prst, govorimo o primarni sukcesiji.

Sekundarna sukcesija je precej bolj razširjen proces kot primarna. Večji del t.i. naravnega rastlinstva je produkt sekundarne sukcesije. Večina današnjih gozdov na planetu je sestavljena iz sekundarnega rastja, ki uspeva na prej, zaradi kmetijske rabe ali drugih vzrokov s požiganjem in izsekovanjem očiščenih območjih (Tivy 1993, 157). Sekundarna sukcesija poteka veliko hitreje kot primarna - od 10 do 1000 let (Tivy 1993) - in je močno odvisna od količine hranil $\mathrm{v}$ tleh in klime. Najhitreje poteka na prej obdelanih tleh (po opustitvi kmetijstva). V Severni Ameriki traja okoli 100-250 let, da na območju, kjer so bila prej polja, zraste gozd. V humidni klimi se ta čas precej podaljša. Gozdovi v okolici templja Angkor Wat so bili uničeni pred približno 500-600 leti, a se še dandanes razlikujejo od gozdov v okolici, ki jih požar ni prizadel (Tivy 1993, 160).

Začetek sukcesije predstavlja kolonizacija invazivnih oziroma t.i. pionirskih vrst (Tivy 1993). Pionirske vrste so prve, ki kolonizirajo oz. naselijo še neporasla, torej gola, ogolela kamnita ali peščena tla, ki jim predstavljajo rastišče in tvorijo pionirske združbe (Geografski terminološki slovar 2005; Jogan 2000). 
Slika 2: Sekundarna sukcesija

Figure 2: Secondary succession

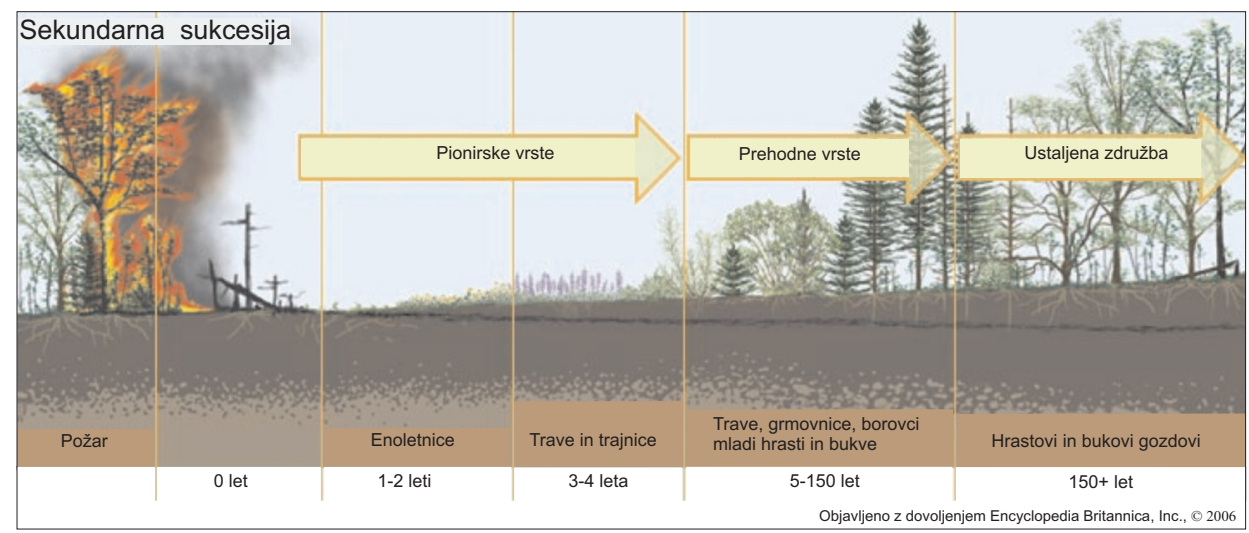

Vir/source: Encyclopedia Britannica 2009

Običajno imajo takšne vrste majhna semena, ki jih raznaša veter, ter sposobnost preživetja na odprtem, klimatološko stresnem in pogosto s hranili revnem in nestabilnem substratu (Tivy 1993).

Funkcija pionirskih vrst je obogatitev tal z dušikom, dvig sposobnosti kapacitete vlage, zaščita pred erozijo, stabilizacija rastišča idr. (Medmrežje 1). V ta namen so se rastlinam razvile dolge korenine, na koncu koreninskih laskov pa bakterije, ki iz zraka vežejo dušik, ter listi, ki omogočajo transpiracijo. Tako kolonizacija kot reprodukcija potekata hitro. Nekatere vrste, kot so npr. lišaji in nekatere druge rastline, povzročajo razpad kamnine in prispevajo organski material k formiranju prsti. To omogoča lažjo naselitev novih organizmov, ki vstopajo v takšno okolje, kjer lahko preživijo in konkurirajo pionirskim vrstam. Na takšen način organizmi v naslednji fazi sukcesije prevzamejo habitat od pionirskih vrst (Medmrežje 3).

Kolonizacija je odvisna od prevladujočih klimatskih razmer, razpoložljivosti in sposobnosti širjenja semen (Medmrežje 3). Med pionirskimi vrstami so najpogostejši lišaji, mahovi ter trave, pogostokrat pa tudi bakterije, ki so lahko prisotne tudi v končni fazi združbe (Medmrežje 2).

Ena od pomembnih lastnosti pionirskih vrst je prilagoditev na svetlobo. Svetloljubne rastline so v konkurenčnemu boju sicer na slabšem, saj jih sencoljubne z zasenčenjem lahko zatrejo. Vendar ima kot vsaka, tudi ta pomanjkljivost določene prednosti, ki jim omogočajo možnost preživetja. Prenašajo polno osvetlitev in lahko uspevajo na odprtih površinah, v slabši mikroklimi, ker je tam tudi bolj toplo in bolj suho. Mnoga svetloljubna drevesa rodijo veliko količino drobnih semen, ki jih veter raznaša na velike razdalje, npr. vrbe, topoli in breze. To jim omogoča naselitev na novih rastiščih. Svetloljubne rastline se zato uveljavijo posebno v začetnih sukcesijskih stopnjah biocenoz (Lovrenčak 2003, 45).

Končni rezultat sukcesije so popolne združbe. Vrste tu živijo v medsebojni odvisnosti v stabilnem okolju, ki se ne spreminja, izvzemši sezonske ter okoljske spremembe. Navkljub temu so klimaksi - kot imenujemo ustaljene končne združbe - na dolgi rok začasne združbe, 
četudi se okolje stabilizira in ni nikakršnih motenj s strani človeka, invazivnih vrst ali bolezni. Proces evolucije namreč poteka neprekinjeno, enako geološke spremembe. Sukcesija tako predstavlja del naravnega stanja ekosistema, manjše spremembe pa se vseeno dogajajo, četudi je klimaks že nastal (Medmrežje 2). Za razliko od začetnih sukcesijskih nizov se v klimaksu organska snov ne kopiči. To pomeni, da sta letna produkcija in pritok enaka letni porabi in odtoku. Kot produkt naravnih razmer ločimo klimatski in edafski klimaks. Klimatski klimaks je združba, ki je v ravnotežju z makroklimo, edafski klimaks pa nastane z močnim delovanjem neklimatskih naravnogeografskih dejavnikov v biotopu, ki preprečujejo nastanek klimatskega klimaksa. Kot posledica vzdrževanja razmer v združbi s strani človeka nastane disklimaks (Lovrenčak 2003, 150).

\section{PRODIŠČA}

Transportiranje gradiva s pomočjo vode poteka na tri različne načine; v raztopini, v suspenziji ter s kotaljenjem po dnu struge. Večji del raztopljenega materiala prinese v vodotoke podzemna voda. Padavinska voda, ki pronica skozi tla do nepropustne matične podlage, $\mathrm{v}$ prsti in razpokah v kamnini raztaplja različne minerale. Del te, z minerali nasičene vode, priteče v vodotok. Na zmožnost prenašanja raztopljenih snovi v vodi hitrost toka ne vpliva, pač pa kemične lastnosti vode oz. sprememba le-teh. Na ta način reke vsako leto v ocean odnesejo okoli 4 milijarde ton gradiva.

Večina vodotokov (toda ne vsi) prenese največji delež gradiva v suspenziji. Motnost vode je najjasnejši znak za visok delež gradiva v suspenziji. Tako se prenaša glina, melj in fini pesek, med poplavami tudi večji delci. Količina gradiva v suspenziji je odvisna od hitrosti vode in velikosti delcev. Večji kot je delec, hitreje ob zmanjšani hitrosti vode pade na dno struge. Poleg velikosti sta pomembni tudi oblika in specifična teža delca, ki vplivata na hitrost posameznega delca v suspenziji. Ploski delci tonejo skozi vodo počasneje kot zaobljeni, delci z večjo gostoto pa hitreje kot tisti z manjšo.

Večji delci se premikajo po dnu struge s kotaljenjem, drsenjem in poskakovanjem. Pri vodni eroziji imajo ti delci največjo vlogo, saj s pomočjo njih voda premika in brusi druge delce. Medtem ko transport v suspenziji in raztopini potekata stalno, se večji delci premikajo le občasno, kadar je moč vode zadostna za njihovo premikanje. Sposobnost vodnega toka za transport gradiva je opisana z dvema kriterijema: prostornino, ki izraža maksimalno količino materiala, ki ga lahko prenese določen rečni tok, ter sposobnost toka za prenos maksimalne velikosti delca. Večja je količina vode v strugi, večja je kapaciteta transporta. Na sposobnost toka za prenos maksimalne velikosti delca močno vpliva hitrost toka. Hitrejši je tok, večje delce lahko voda prenaša v suspenziji in po dnu struge. Sposobnost vodnega toka narašča s kvadratom njegove hitrosti: če se hitrost poveča za dvakrat, se sposobnost za štirikrat. Zato so največji kamni, ki jih pogosto vidimo sredi struge ob povprečnem vodostaju, preneseni ob naslednji povodnji, ko se sposobnost za transport močno poveča. Ko se hitrost rečnega toka zmanjša, njegove zmožnosti za transport gradiva upadejo (Tarbuck in Lutgens 2002, 275-276).

Material, ki ga reka odlaga na svoji poti, imenujemo aluvij. Material v aluviju je sortiran in so posamezne plasti lepo vidne (Tarbuck in Lutgens 2002, 277). Pomanjkanje plastovitosti 
kaže na turbulentost toka ali pa na kasnejše presortiranje gradiva. Prekinitve sedimentacije imajo pomembno vlogo pri procesu pedogeneze. Največji delci se odložijo najprej, sledijo manjši, na vrhu se odloži najfinejši material. Najbolj plastovito so odloženi najfinejši delci (Shaetzl in Anderson 2005, 629). Poznamo več različnih vrst aluvija. Najdemo jih lahko v sami strugi, v rečnem ustju ali pa ob bregovih reke (Tarbuck in Lutgens 2002, 277).

Odkladnino, sestavljeno iz peska in proda, ki prekrije zemljišče, navadno ob rečnem toku ali v sami strugi, imenujemo prodišče (Geografski terminološki slovar 2005). Gre za začasne oblike, saj reke ob visoki vodi delce odnašajo dolvodno, na istem mestu pa odlagajo nov material. Prodišča lahko nastanejo na različne načine. Največkrat nastajajo na notranjih delih rečnih zavojev - meandrov, kjer se reki zaradi fizikalnih zakonov hitrost zmanjša. Na nasprotni strani - na zunanjem delu zavoja, pa se reki hitrost poveča in tam močno erodira (Tarbuck in Lutgens 2002, 277). Glede na to, da poteka bočna erozija, se meandri premikajo navzdol po dolini. V ozek pas, ki nastane med dvema zaporednima meandroma, se pogostokrat vreže reka in tako skrajša svoj tok. Nekdanji polkrožni del struge imenujemo mrtvica (Tarbuck in Lutgens 2002, 103).

Material se lahko začne odlagati tudi na samem dnu sredi struge. To povzroči, da se rečni tok razcepi v več manjših pramenov (Tarbuck in Lutgens 2002, 277). Takšen tok, ko reka teče $v$ številnih pramenih med prodišči, imenujemo pramenasti tok. Značilen je za reke v visokogorju, subpolarnem in puščavskem svetu (Natek 2004, 125). V visokogorju nastane pramenast tok na območjih, kjer manjši hudourniški potoki pritekajo v reke in se jim hitro zmanjša hitrost in s tem transportna moč. Tako je odloženega precej gradiva in reka vanj vreže pramene, po katerih teče. Vreže jih lahko tudi v material, ki ob večjih deževjih splazi z rečnih bregov in tako delno zajezi reko. Pramenast tok je značilen tudi za območja, kjer se stikata vlažno in sušno podnebje. Na območju sušnega podnebja se močno poveča izhlapevanje in s tem zmanjša transportna kapaciteta reke. V subpolarnih območjih se reke, ki pritekajo izpod ledenikov, pramenasto vrezujejo v morensko gradivo, ki ostaja ob umikanju ledenika. Tudi tu reke tvorijo pramenaste tokove (Tarbuck in Lutgens 2002, 277). Poleg naravnih vzrokov za nastanek prodišč so pomembni tudi antropogeni - različni infrastrukturni objekti ob ali v sami strugi so lahko vzrok za nastanek prodišč.

\section{METODOLOGIJA}

Raziskave smo opravili na prodiščih treh rek, Save Dolinke, Save Bohinjke in reke Save med naseljema Lancovo (sotočje Save Bohinjke in Save Dolinke) ter Podbrezjami (sotočje Tržiške Bistrice in Save). V vsaki reki smo izbrali po tri prodišča (skupaj devet), ki smo jih podrobneje preučili. Prodišča smo poimenovali s prvo črko imena vodotoka ter številko 01, 102 in 103, kjer 101 pomeni prvo obravnavano prodišče, najvišje ob toku.

Meritve smo izvajali poleti, ko so vodostaji rek najnižji, in sicer v mesecu avgustu leta 2009.

Pri delu smo uporabili kartografsko metodo dela. Na posameznem prodišču smo skušali izločiti območja oz. pasove, ki bodisi morfološko, bodisi po floristični sestavi tvorijo samostojen del. Pri določanju vrst smo si pomagali z različnimi določevalnimi ključi. Višino popisne ploskve smo izmerili glede na najnižji vodostaj reke. Pri merjenju višine smo si 
pomagali z doma izdelanim merilnikom, sestavljenim iz 1,5 m visoke navpične kovinske palice, na katero je bil pravokotno nameščen nosilec, ki ga je bilo mogoče poljubno nastavljati po višini. Na tem pravokotnem nosilcu je bila pritrjena vodna tehtnica ter naprava, ki oddaja laserski žarek. Merjeno mesto smo označili s širšim lesenim količkom, v katerega smo tik nad prodom usmerili laserski žarek. Višino kovinskega nosilca nad vodno gladino smo izmerili z navadnim kovinskim metrom. Ostale elemente popisa, ki izhajajo iz popisnega lista, smo določili s pomočjo različnih pripomočkov (merilna letev, kompas) in kart (geološka, geomorfološka), ali pa smo jih ocenili. Popisni list je povzet po popisnem listu, ki ga je za slušatelje predmeta Biogeografija na Filozofski fakulteti v Ljubljani sestavil dr. Blaž Repe. Vsako prodišče smo tudi natančno fotografirali.

Slika 3: Lega preučevanega območja z označenimi izbranimi prodišči

Figure 3: Map of study area with selected point bars

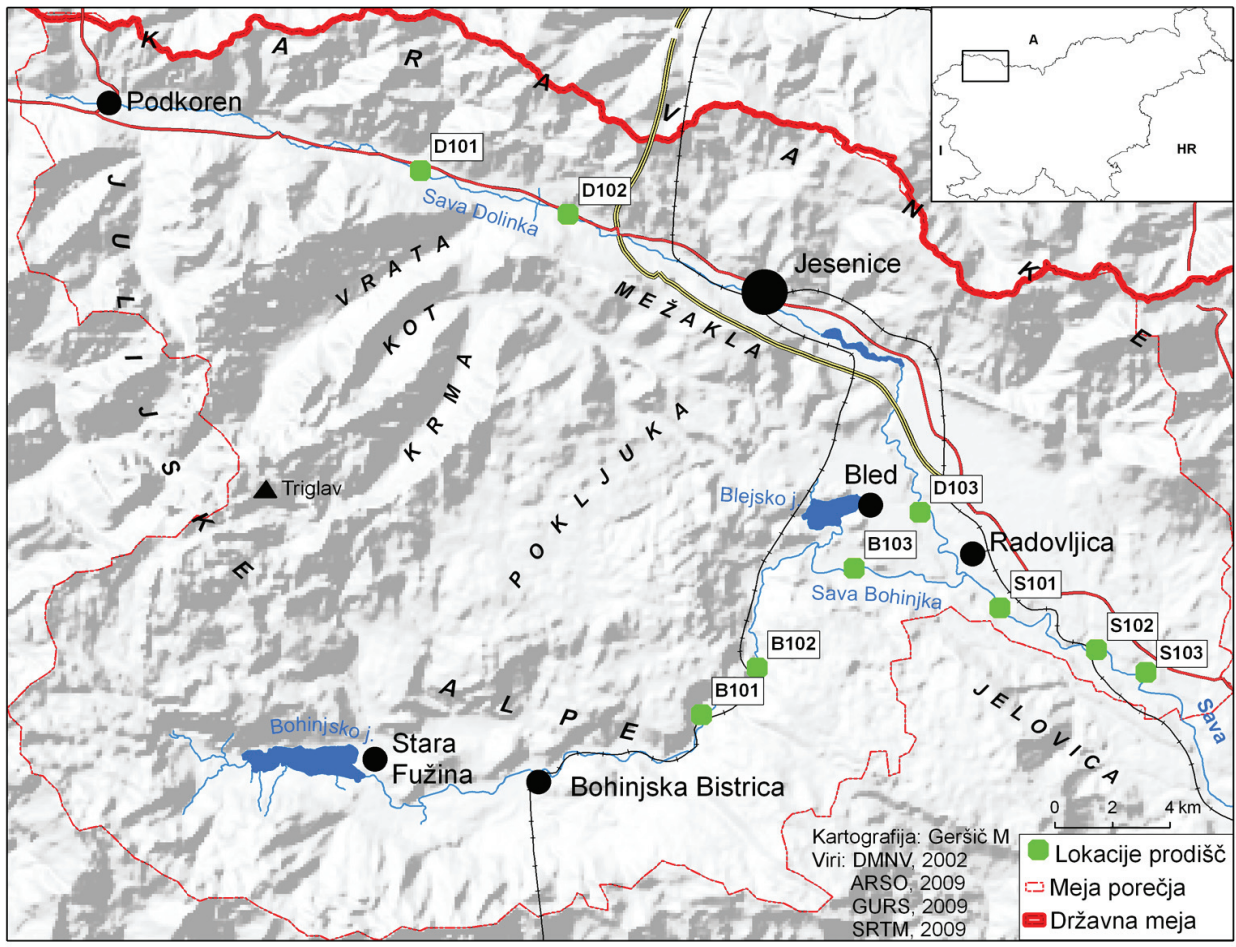

\section{REZULTATI RAZISKAVE}

Obravnavana prodišča so različnega nastanka. Razdelimo jih lahko v tri skupine (slika 4). V prvo skupino spadajo klasična prodišča, nastala na notranji strani rečnega zavoja. V skupino pramenastih prodišč, ki so v Sloveniji značilna za zgornje toke rek, spada prodišče v zgornjem toku Save Dolinke, v tretjo skupino pa spadajo prodišča, ki so nastala kot posledica 
človeških posegov v strugo ali drugih naravnih procesov. Človekovi posegi, ki botrujejo nastanku prodišč, so največkrat izgradnja infrastrukturnih objektov, ki so v strugi v celoti ali le njihovi posamezni elementi. Med ostale naravne dejavnike, ki povzročajo nastanek prodišč, smo uvrstili podorni material, ki lahko povzroči spremembo rečne dinamike do te mere, da reka začne erodirati nasprotni breg in nastane blag zavoj.

Slika 4: Tipi obravnavanih prodišč

Figure 4: Types of explored point bars

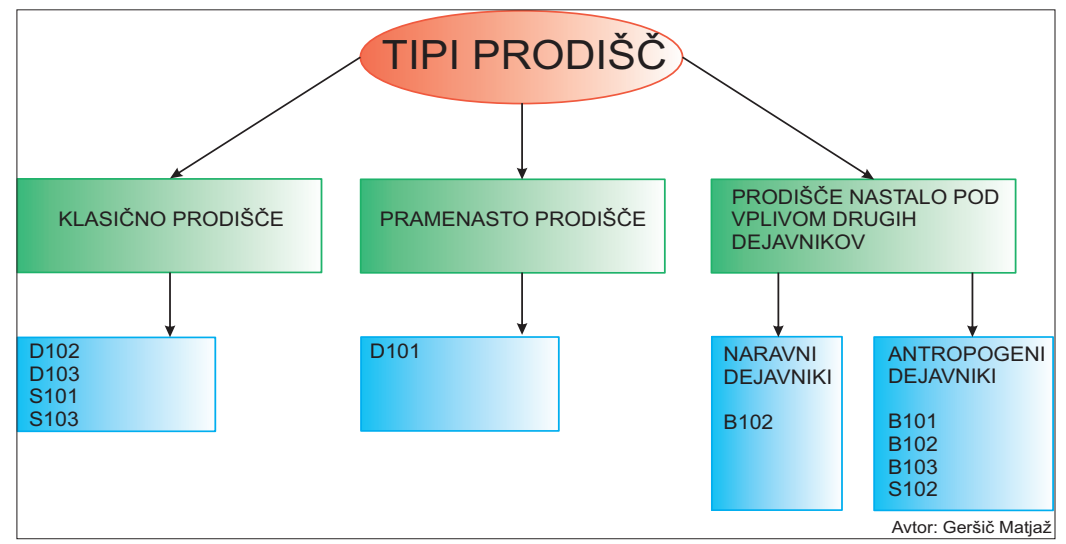

Sestava aluvialnega gradiva na prodiščih je odvisna od kamninske zgradbe porečja. Glede na pretežno karbonatno sestavo porečja je zastopanost tovrstnega gradiva prevladujoča tudi na prodiščih. Gradivo je različnih frakcij, od velikih skal, ki so zelo verjetno glacialnega izvora, do najfinejših glinastih in meljastih delcev. Poleg klasičnih prodnikov lahko na prodiščih najdemo tudi konglomerat, v zgornjem toku Save tudi peračiški tuf. Delci so praviloma lepo zaobljeni, kar kaže na dolgotrajen rečni transport. Izjema je prodišče D101, kjer je v prvem pasu zaobljenih prodnikov manj in prevladuje ostrorobo gradivo. Vzrok je kratkotrajnost transporta gradiva v potoku Belca, ki se tu izliva v Savo Dolinko in zaradi zmanjšanja hitrosti toka odloži veliko gradiva. Prodišče B102 sestavljajo tudi velike skale, ki so podornega izvora.

Razlika v velikosti med gradivom v začetnem in končnem delu prodišča je na nekaterih prodiščih opazna, drugod ne. Praviloma pa se velikost gradiva zmanjšuje od začetne do končne točke prodišča. Pri klasičnem tipu prodišč je v začetnem delu prisotno grobo kamenje in večje skale, ki so lahko del prodišča ali pa se nahajajo nekoliko višje ob toku. To gradivo predstavlja neke vrste oviro, ki odvzema potencialno moč vodi in tako nekoliko zavaruje rastline na samem prodišču.

Oblika prodišč je zelo različna. Pri klasičnih prodiščih prevladuje polkrožna oz. srpasta oblika, pramenasto prodišče ima izrazito podolgovato obliko, katere širina je relativno konstantna, le v skrajnem končnem delu se nekoliko zoži. Ostala prodišča so različnih oblik, praviloma so najširša v osrednjem delu. 
Med antropogenimi vplivi na prodišča prevladuje kopanje peska in proda, odlaganje gradbenega materiala, uporabljajo jih tudi ribiči za dostop do reke. Praktično ni prodišča, kjer ne bi opazili kurišča in raznih odpadkov (pločevinke, steklenice, druge smeti). Nekatera prodišča (D103, B103, S101, S103) se v poletnem času spremenijo v plaže, ki jih obiskujejo tako domačini kot tujci.

V neposredni bližini prodišč (z izjemo prodišč B101 in B102) so locirana kmetijska zemljišča različnih kategorij (travniki, njive in pašniki). V Zgornjesavski dolini (prodišča D101 in D102) prevladujejo travniki in pašniki. V bližini prodišča D103 je obsežno kmetijsko zemljišče, kjer so pred leti sadili koruzo, danes pa ga porašča lucerna. Prav tako je košnji namenjeno območje v neposredni bližini prodišč S102 in S103. Kmetijsko zemljišče zraven prodišča S101 je razdeljeno na pašnik, travnik in njivo. Na njivi je posejana koruza. Prod v ornici je sicer opazen, a ga količinsko ni tako veliko, da bi onemogočal strojno obdelavo tal.

Vpliv kmetijske dejavnosti na prodiščne habitate je dvosmeren. Iz njiv in travnikov veter ali živali zelo hitro zanesejo semena kulturnih rastlin oz. poljščin na prodišče, kjer ta semena pogosto vzklijejo in lahko rastejo do močnejšega jesenskega deževja, ko jih visoka voda odnese. Na terenu smo opazili tri takšne kulturne rastline (koruzo, paradižnik in sončnico). Poleg omenjenega vpliva sklepamo, da kmetijska dejavnost na prodiščne habitate vpliva tudi z uporabo agrokemičnih sredstev, ki jih voda izpira v nižje horizonte in se odtekajo proti prodišču. Za ugotavljanje tovrstnih vplivov bi bile potrebne raziskave vsebnosti mineralnih in organskih hranil na prodiščih, katerih pa v okviru te raziskave nismo opravili.

Biologi obravnavajo prodišča kot poseben habitatni tip (Šilc 2000). Habitatni tip je definiran kot vizualna enota narave, ki se po obliki, vsebini in procesih loči od sosednjih (Dobravec 2001).

Nekatera prodišča na obravnavanem območju so gola in neporasla, druga porašča različno rastlinstvo. Izbrana prodišča rastlinstvo porašča $\mathrm{v}$ pasovih, ki se jasno ločujejo eden od drugega. Celotno območje prodišča, od rastlinskih vrst v drugem pasu, vključno z vrstami v gozdnih fitocenozah, ki se razraščajo že izven prodišča, spada v prvi sukcesijski niz, torej gre za pionirske vrste. Glede na jasno delitev rastlinstva na posamezne pasove znotraj niza smo prvi niz razdelili na več sukcesijskih mikronizov oz. pasov. Posamezen sukcesijski mikroniz se glede na kombinacijo rastlinskih vrst in značilnosti poraščanja jasno ločuje od sosednjega, kljub temu, da so za vse mikronize, opisane na prodišču, značilne pionirske rastlinske vrste. Število teh mikronizov se med prodišči malenkostno razlikuje. Odvisno je od več dejavnikov, predvsem od površine prodišča, tipa prodišča, naklona prodišča, frakcij aluvialnega sedimenta, pogostnosti poplav, svetlobe ipd. Večina pasov je najbolj jasno izraženih v osrednjih delih prodišč, kar pa ne velja za prvi pas, ki ni poraščen. Ta pas je običajno najširši v začetnem delu prodišča, kjer je moč naraščajoče vode največja. V začetnih in končnih delih se pasovi združujejo v obrečni pas. Tu so zastopane različne vrste higrofilnih rastlin.

V prvi pas spada neporaščeno aluvialno gradivo različnih frakcij. Običajno je neporaščen tudi tisti del prodišča, kjer se s prodiščem stika dovozna pot.

Drugi pas nesklenjeno poraščajo različne rastline, a zgolj v zeliščni plasti. Ostale plasti niso razvite. Med rastlinskimi vrstami prevladujejo navadni repuh (Petasites hybridus), rdeča vrba (Salix purpurea), črni topol (Populus nigra), navadna krvenka (Lythrum salicaria), 
gozdna potočarka (Rorippa sylvestris), dolgolistna meta (Mentha longifolia), črni glavinec (Centaurea nigra), pisana preslica (Equisetum variegatum), navadna milnica (Saponaria officinalis), navadni regrat (Taraxacum officinale), plavajoča sladika (Glyceria fluitans), trstična pisanka (Phalaris arundinacea), pasja šopulja (Agrostis canina), na prodiščih D101 in S102 tudi ozkolistno ciprje (Epilobium angustifolium), prodiščna hrustavka (Chondrilla chondrilloides), trebušasta zvončnica (Campanula cochleariifolia) ter cipresasti mleček (Euphorbia cyparissias).

$\mathrm{V}$ prvem, drugem ali tretjem pasu se na mestih, kjer se je odložil finejši material, pogosto razraščajo dresni; ščavjelistna (Polygonum lapathifolium) in breskova (Polygonum persicaria), poleg teh pa tudi veliki trpotec (Plantago major) in različne vrste detelj (Trifolium hybridum, T. repens).

$\mathrm{V}$ tretjem pasu prevladujejo različne vrste vrb v zeliščnem in grmovnem sloju. Šilc (2000) tovrstne združbe imenuje grmišče sive in rdeče vrbe (Salicetum incano-purpureae; Šilc 2000). Drevesni sloj tu še ni razvit. Poraščenost je sklenjena. Med vrbami prevladujeta rdeča vrba (Salix purpurea) in siva vrba (Salix eleagnos). V zeliščnem sloju so zastopane vrste iz drugega pasu.

$\mathrm{V}$ drugem, tretjem in četrtem pasu se pojavljajo tudi invazivne oz. tujerodne vrste, ki ponekod tvorijo samostojne sestoje in jih lahko izločimo kot povsem samostojen pas. Od osmih tujerodnih vrst, ki so opisane na biološkem portalu (Medmrežje 4), smo na prodiščih našli štiri. Nekateri avtorji k invazivnim vrstam prištevajo še številne druge, mdr. robinijo (Robinia pseudoacacia), ki smo jo našli na nekaterih prodiščih. Najpogostejše invazivne vrste so žlezava nedotika (Impatiens glandulifera), kanadska zlata rozga (Solidago canadensis), enoletna suholetnica (Erigeron annuus) in japonski dresnik (Reynoutria japonica).

Četrti pas je prehodni pas med prodiščem oz. prodiščnim rastlinstvom in gozdom ali kmetijskimi površinami izven prodišča. Sestavljajo ga predvsem vrste gozdnih robov, ki jih Zupančič in Žagar (1998) ravno tako opisujeta kot pionirske vrste. Vrbe v tem pasu običajno niso več zastopane. Najbolj je razvit grmovni sloj. Prevladujejo rdeči dren (Cornus sanguinea), navadna kalina (Ligustrum vulgare), beli gaber (Carpinus betulus), navadna krhlika (Frangula alnus), črni bezeg (Sambucus nigra), enovrati glog (Crataegus monogyna), brogovita (Viburnum opulus) ter dobrovita (Viburnum lantana).

Gozd, ki poleg kmetijskih zemljišč sledi prehodnemu pasu, sestavljata predvsem fitocenozi Alno incanae-Pinetum sylvestris var. geogr. Omphalodes verna in BrachypodioPinetum. Sledna je na nekoliko višji razvojni stopnji in že vsebuje vrste iz primarnih, torej hrastovih, gabrovih in bukovih gozdov, ki so tu uspevali, preden so bili antropogeno izkrčeni (Zupančič in Žagar 1998).

\section{ZAKLJUČKI}

Če generaliziramo rezultate preučevanja, dobimo teoretični model prodišča (slika 5). V teoretičnem modelu je predstavljeno pet pasov, ki si sledijo od reke proti gozdnemu pasu.

Primarna sukcesija poteka torej od golega proda, zelnatih vrst v drugem pasu, sestojev vrb, vrst v prehodnem pasu, gozdov bora do omenjenih hrastovih, gabrovih in bukovih gozdov. Kmetijska zemljišča, ki mestoma sledijo prehodnemu pasu, so namenjena predvsem 
Slika 5: Sukcesijski mikronizi na prodiščih-grafični model

Figure 5: Successive microstages on point bars-graphic model

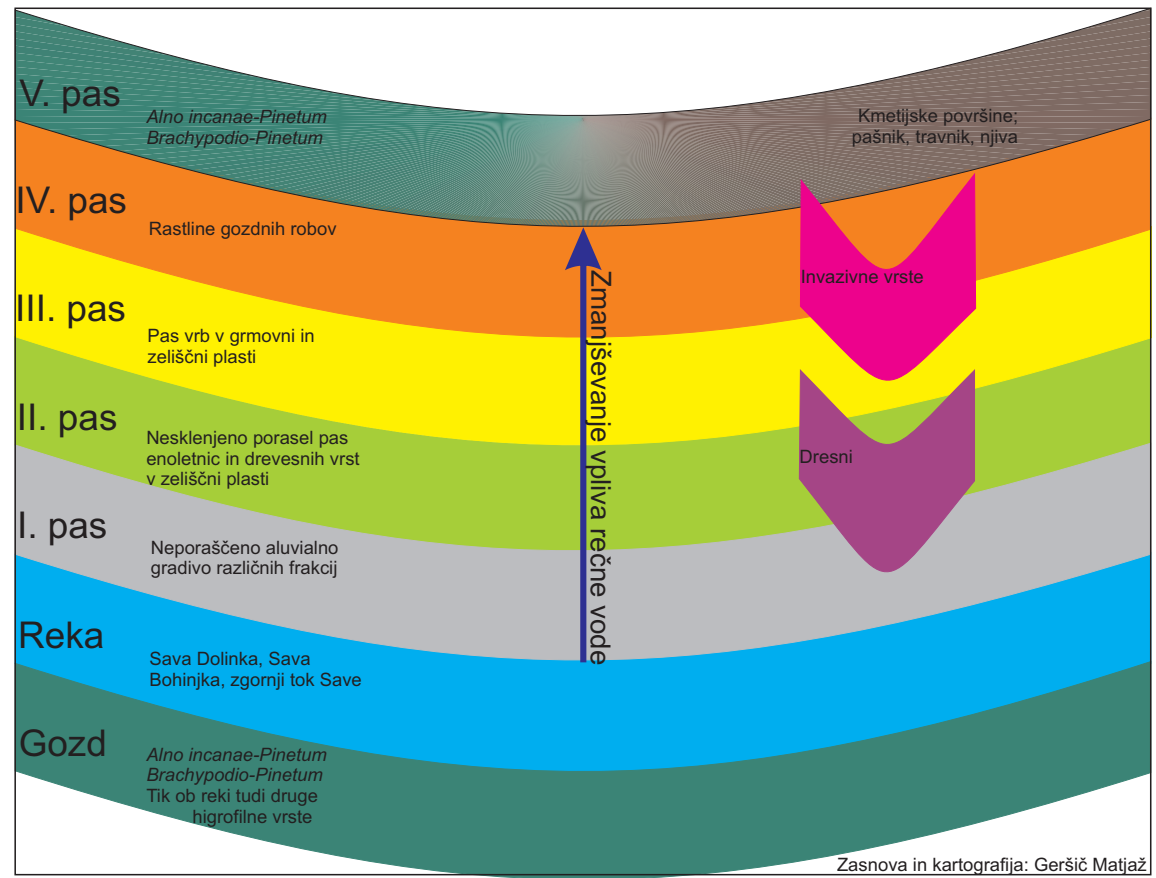

\section{Slika 6: Sukcesija na prodiščih}

Figure 6: Succession on point bars

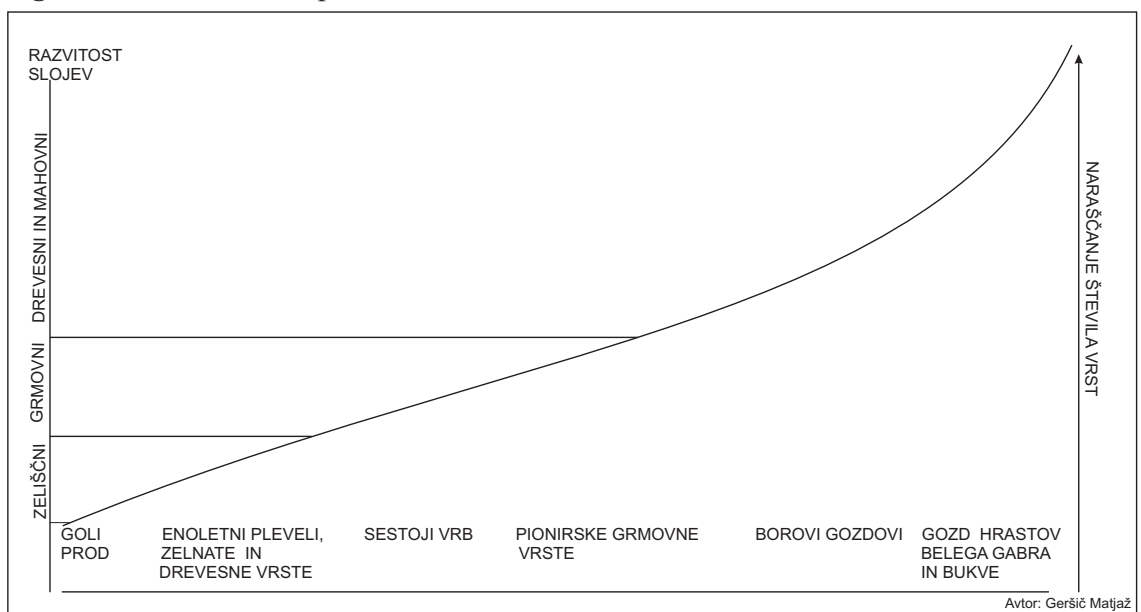


paši in košnji, na nekaterih mestih tudi njivam. Breg nasproti prodišča je običajno poraščen z drevesnimi, grmovnimi in zeliščnimi vrstami. Razvita je tudi mahovna plast. Tik ob reki prevladujejo higrofilne vrste, višje pa vrste, ki so opisane v prej omenjenih gozdnih fitocenozah. Mahovni sloj v prvem, drugem in tretjem pasu ni razvit.

Vpliv poplav na prodiščno rastlinstvo smo lahko opazovali v mesecu septembru 2009, ko je Gorenjsko zajelo močno deževje. Teden dni po deževju, ko se je voda spustila nazaj na normalni nivo, smo ponovno obiskali prodišče S101. Ugotovili smo, da je bilo celotno prodišče poplavljeno. Vrste v prvih pasovih so ostale, del proda je odneslo, tako da so bile ponekod vidne koreninice.

\section{Slika 7: Stanje prodišča S101 pred in po poplavi (foto: M. Geršič)}

Figure 7: The state of a point bar S101 before and after flooding (photo M. Geršič)

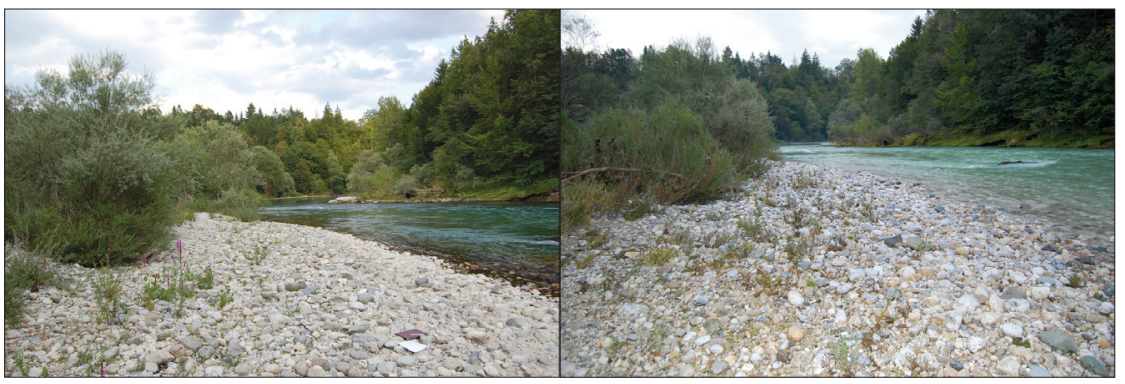

Na nekaterih mestih, predvsem za večjimi grmi, je voda odložila finejše frakcije materiala. Najbolj uničen je bil prehodni pas, predvsem njegov zeliščni sloj. Tu je bila razlika v stanju pred in po povodnji najbolj očitna. Na prodišču B103 smo lahko v času visokega nivoja vode opazovali rastline, ki so bile dlje časa poplavljene. Navadnemu repuhu, dolgolistni meti in različnim vrstam dresni visoka voda ni škodovala. Na listih repuha se je odložilo fino gradivo in manjši prodnik.

V. Petkovšek v svojem delu z naslovom Planinsko cvetje v nižini (1939) opisuje bogato alpsko floro, ki vsakoletno vzklije na rečnih bregovih iz semen, ki jih hudourniki naplavljajo v Savo Dolinko. Na terenu je bilo res opaziti razliko med vrstami v začetnih pasovih na prodiščih D101 in D102 ter na ostalih prodiščih, vendar vrst, ki so deklarirane kot izrazito alpske, nismo našli veliko. Omeniti moramo prodiščno hrustavko (Chondrilla chondrilloides), trebušasto zvončnico (Campanula cochleariifolia) in ozkolistno ciprje (Epilobium angustifolium). Od omenjenih treh Lippert (1990) le za rastišča trebušaste zvončnice opisuje izključno skalne razpoke, skalni grušč in gruščnate trate. Rastišča prodiščne hrustavke so vezana izključno na rečna prodišča. V Sloveniji je bila najdena na prodiščih Soče in Save (Wraber 1965). Ozkolistno ciprje raste na različnih nadmorskih višinah od nižine do nad 2000 m (Lippert, 1990). Vse tri omenjene vrste smo našli le na obeh prodiščih v srednjem toku reke Save Dolinke, nižje pa ne. Razlog, da se omenjene vrste nižje ob toku ne pojavljajo, je lahko v drugačnih klimatskih razmerah, ali pa je pot diaspor po toku navzdol prekinjena z različnimi infrastrukturnimi objekti v strugi. 


\section{SKLEP}

Glede na izredno dinamičnost prodišč kot habitatov, za ohranjanje katerih je nujna naravna dinamika rečnih tokov, lahko vsak najmanjši poseg $\mathrm{v}$ rečno strugo ali v prodišče povzroči motnjo v tej dinamiki. Posledično lahko to pomeni uničenje prodišča kot habitata in izgubo vseh drugih naravovarstvenih funkcij, ki jih opravlja z naravnim obrežnim rastlinstvom poraslo prodišče. Nujno je torej upoštevati zakonske predpise, ki urejajo ohranitev prodiščnih habitatov in ostala priporočila znanstvenikov, kako posegati v naravno okolje, da bi bili človeški vplivi na naravne procese minimalni. Kljub temu da je vzorec izbranih prodišč v raziskavi številčno majhen, rezultati kažejo nekatere pomembne značilnosti sukcesije na prodiščih. Za natančno določitev vpliva vseh izbranih spremenljivk bi bilo potrebno preučiti vsa prodišča na določenem vodotoku, za kar bi potrebovali dodatno opremo za terenska raziskovanja, saj so nekatera prodišča zaradi različnih vzrokov težko dostopna. Na podlagi analize vseh prodišč bi lahko podali določene zakonitosti. Smiselna bi bila tudi raziskava procesa sukcesije (primarne in sekundarne) na ostalih območjih, kjer le-ta poteka. Tovrstne rezultate bi lahko uporabili tudi pri revitalizaciji določenih degradiranih okolij.

\section{Viri in literatura}

Dobravec, J. 2001: Habitatni tip, nov pojem v varstvu narave. Proteus 63, 8. Ljubljana. Encyclopedia Britannica. Medmrežje: http://www.britannica.com/EBchecked/topic /178264/ecological-succession (30.09.2009).

Geografski terminološki slovar. Ljubljana 2005.

Jogan, N. 2000: Neofiti - rastline pritepenke. Proteus 63, 1. Ljubljana.

Lippert, W. 1990: Alpsko cvetje. Ljubljana.

Lovrenčak, F. 2003: Osnove biogeografije. Ljubljana.

Medmrežje 1: http://www.life.uiuc.edu/biol00/lectures/f06lects/03f06-succession. html\#primary (30.9.2009).

Medmrežje 2: http://everything2.com/?node_id=1986240 (30.9.2009).

Medmrežje 3: http://www.bookrags.com/research/pioneer-species-wob/ (10.10.2009).

Medmrežje 4: http://www.bioportal.si (10.10.2009).

Natek, K. 2004: Geomorfologija, skripta. Oddelek za geografijo, Filozof. fakulteta. Ljubljana. Petkovšek, V. 1939: Planinsko cvetje v nižini. Planinski vestnik 4. Ljubljana.

Schaetzl, R. J., Anderson, S. 2005: Soils: genesis and geomorphology. Cambridge, New York. Šilc, U. 2000: Habitatni tipi Slovenije, prodišča - mozaik habitatnih tipov. Proteus 63, 4. Ljubljana.

Tarbuck, E. J., Lutgens, F. K. 2002: Earth: an introduction to physical geology. Upper Saddle River.

Tivy, J. 1993: Biogeography: a study of plants in the ecosphere. Burnt Mill.

Wraber, M. 1965: Združba berinijevega jajčarja in alpske hrustavke (Leontodon berinii-

Chondrilletum assoc. nova) na soških prodiščih pri Bovcu. Varstvo narave 4. Ljubljana. Zupančič, M., Žagar, V. 1998: Obrečna borovja zgornjega toka Save (Slovenija). Razprave IV. razreda SAZU, 39, 9. Ljubljana. 


\section{SUCCESSION ON THE POINT BARS OF THE SAVA RIVER}

\section{Summary}

Succession is one of the processes, identifying the changes of vegetation on the Earth. This is an evolutionary development from bare ground to the climax association, which is in dynamic balance with its environment. We differentiate between primary and secondary succession. Primary succession takes place in areas where soil as a mixture of mineral and organic compounds has not yet emerged. Such environments are areas of volcanic eruptions, extensive stone and sandy areas (dunes, etc.), areas uncovered by the retreat of a glacier and the newly formed land areas. Secondary succession takes place in areas where the vegetation was completely or partially destroyed due to various reasons, however, a layer of soil has remained. The reasons for the destruction of vegetation are the following: blaze, strong winds, drought, flooding, introduction of invasive species, soil erosion, and various human interference with the natural environment.

The entire process of succession is composed of several succession stages, which replace one another in the natural habitat. In the initial succession stages pioneer plant species emerge, which are capable of surviving in stressful environments thanks to a wide ecological amplitude. Pioneer plant species protect soil from erosion and enrich it with nitrogen and thus stabilize the habitat. Among the most common pioneer species there are lichens, mosses and grasses, but also bacteria that may be present in the final stage of the association.

One of the environments where primary succession takes place are also river point bars. These point bars consist of alluvial sediment, transported by the river in suspension or rolled along the bottom of the river bed. This sediment is laden on the spots where the river power is reduced.

In the framework of this research a total of nine point bars were chosen in the Sava Dolinka River, Sava Bohinjka River and upstream of the Sava River to make the analysis according to biogeographic methods.

The above-mentioned point bars are of different origins. They are divided into three groups: in the first group there are classical point bars, emerging on the inner side of the river bend. In the second group there are braided gravel deposits that are characteristic of Slovenian upper river flows (one of these is also the point bar in the upper stream of Sava Dolinka). In the third group there are point bars that are the consequence of human interference into the riverbed and other natural processes.

The anthropogenic impacts on the gravel beds include extracting sand and gravel and disposal of building materials. They are also used by fishermen to access the river. Unfortunately, there are practically no unspoiled point bars as they are polluted with different sorts of refuse (cans, plastic bottles and other dumped materials). Some point bars turn to swimming areas in the summer, visited by both locals and foreigners. In the vicinity of point bars various categories of agricultural land (meadows, fields and pastures) are located. The impact of agricultural activity is evident in the introduction of crops onto point bars.

Some point bars in this area are barren, the others are overgrown with various plant species growing in belts that are visibly different from each other. The whole area of point 
bars is overgrown by pioneer plant species belonging to the first succession stage. The first succession stage was divided into microstages according to the clear division of vegetation into specific belts. Each succession microstage can be distinguished from the neighboring one as it is overgrown with its own specific plant species. The number of these microstages among point bars is slightly different. It depends on several factors, such as area of point bars, size of sediment particles, slope gravel beds, the frequency of flooding, intensity of light, etc. Most of the microstages zones are explicitly expressed in the central parts of the point bars, except for the first microstage, which is not overgrown at all. This microstage is usually the widest in the upriver part of the point bars as a result of the increasing power of water. The initial and final parts of the microstages join in the riverside belt. Different types of hygrophilous plants grow in this habitat.

In the framework of this research the following microstages have been listed:

- The first microstage has no vegetation - it is barren.

- The second microstage is overgrown with various plants, but only in the herb layer. Other layers are not developed. The following plant species can be spotted there: Petasites hybridus, Salix purpurea, Populus nigra, Lythrum salicaria, Rorippa sylvestris, Mentha longifolia, Centaurea nigra, Equisetum variegatum, Saponaria officinalis, Taraxacum officinale, Glyceria fluitans, Phalaris arundinacea, Agrostis canina, on the point bars D101 and S102 there are also Epilobium angustifolium, Chondrilla chondrilloides, Campanula cochleariifolia and Euphorbia cyparissias.

- Polygonum lapathifolium, Polygonum persicaria, Plantago major, Trifolium hybridum and Trifolium repens can be found in the first, second or third microstage on the spots where small size particles of sediment are deposited.

- The third microstage is dominated by different types of willow trees (Salix purpurea and Salix eleagnos) in herb and shrub layer.

- The invasive species (Impatiens glandulifera, Solidago canadensis, Erigeron annuus and Reynoutria japonica) can be found in the second, third and fourth microstage. They sometimes form a separate microstage.

- The fourth microstage represents a transitional belt between the point bars and forest or agricultural areas outside the point bars, which is mainly composed of forest edge species. Shrub layer is the most developed one. Willow trees cannot be found in this habitat. The following species prevail in this microstage: Cornus sanguinea, Ligustrum vulgare, Carpinus betulus, Frangula alnus, Sambucus nigra, Crataegus monogyna, Viburnum opulus and Viburnum lanthana.

- Alno incanae-Pinetum sylvestris and Brachypodio-Pinetum association grow in the forest, following the transitional belt besides agricultural land.

The primary succession on point bars is made up of these microstages: from barren sand and gravel, herbaceous species in the second microstage, associations of willow trees in the third microstage, species in the transitional microstage, to pine, beech and oak forests.

(Translated by Alenka Rozman) 